\title{
Demonstration and Damnation
}

\section{William Blake's Eternal Death of Unbelief JOSHUA SCHOUTEN DE JEL}

Abstract: In Blake's mythopoeia, as well as his personal eschatology, belief is the source of life itself; all creative acts, all visionary episodes, Stem from an individual's belief. "Eternal Death," which is the cycle of Generation, is the result of unbelief. Francis Bacon, Isaac Newton, and John Locke were, for Blake, the triumvirate of culpable votaries for the propagation of rational reductionism which had led to the reification of "Natural Religion" in the form of Deism and Rational Dissent in England and, with the addition of Rousseau and Voltaire, of the apotheosis in France of the Cult of Reason. The French philosophes and the English empiricists were not only at fault for forming the wheels which turned the "dark Satanic Mills?" (M 514 1.8) of man's cognizance but, and what Blake considered their primary offence, of unbelief. This paper will discuss how unbelief is the main cause of division in Blake's universe, accentuated "by the cruelties of Demonstration" (M 578 29.36) of empiricists who "Doubt Doubt \& dont believe without experiment" (NB 609 5-9), and how the Limits placed upon man's fall(s) act as one possible mode of redemption which allows for the return of belief and the individual's creative vision.

Near the end of his life, William Blake proclaimed that "[t]he Old \& New Testaments are the Great Code of Art" (Writings 777). The Laocoön, completed in 1826, rekindles that forthright-fire of The Marriage of Heaven and Hell (1790-3) which Blake had produced nearly thirty-years earlier and similarly recovers that stridently aphoristic voice which was so effective in the "Proverbs of Hell." Throughout those intervening years, Blake consistently incorporated Old and New Testament narratives within his mythopoeia to both glorify and criticize certain moral strands within Christian doctrine almost in equal measure. 
It is evident, however, from the satirization of the law-giving Jehovah of Genesis in The Book of Urizen (1794) and the law-enforcing Moses of Exodus in The Book of Ahania (1795) that Blake's critique tended to fall upon the Old Testament. ${ }^{1}$ Christopher Rowland, in his defence of Blake's worth to biblical exegetes and theologians, observes that Blake "seeks to liberate the Bible from the dominant patterns of interpretation of his day. His exegesis represents a distinctive reformulation of the text" and, though at times the newly-created work of art can be considered quite "formidable," Rowland adds that "problems of exposition" reflect "the interplay between tradition and innovation that has always been such a central feature of New Testament exegesis" (182). ${ }^{2}$ It is the New Testament which acts as the visionary vehicle for the artistically creative process and it is the soteriology of belief as it was preached by Christ that forms the foundation of Blake's redemptive process.

The layering of centuries and the layering of centuries of thought within Blake's work tends to conflate systems and thereby bring to light the parallels which are maintained across those centuries. By associating Christian Orthodoxy with Natural Philosophy — and often by superimposing the liturgical dogma of the Old Testament onto the rational epistemology of empiricists - Blake brings each to bear upon the other.

It is within this context that the Romantic incorporation of a Deistically-infused poetics provided a contemporaneous analogue for Blake's polemical hermeneutics. In his 1826 marginalia of William Wordsworth's "Poems," Blake writes, "I see in Wordsworth the Natural Man rising up against the Spiritual Man Continually, \& then he is No Poet but a Heathen Philosopher at Enmity against all true Poetry or Inspiration" (Writings 782). According to Blake, Wordsworth's reliance upon natural objects neglected the role of the Imagination. Indeed, Blake asserts that "Imagination is the Divine Vision not of The World, or of Man, nor from Man as he is a Natural Man, but only as he is a Spiritual Man" (Writings 783). The distinction made is between the "Natural Man" and the "Spiritual Man" and the way in

1 This is partly avowed by Blake himself in the Laocoön where he adds that "Jesus \& his Apostles \& Disciples were all Artists" (Writings 777). The emphasis here is on the New Testament.

2 Eric Pyle has noted that, "[t]hough the Bible, for Blake, is undoubtedly the great code of art, and the writings of the prophets are the greatest example of wisdom, appearances of the Bible as a physical book in his visual work are not generally positive" (263). In part, this is a pictorial representation of the codification Blake feared and this is also why Rowland's observation of the innovative potential of the New Testament is so apt. 
which each creature operates within the fallen world, observes the fallen world and understands his role within the fallen world. Blake believed that the "Natural Man," limited to the natural world, cannot move beyond the confines placed upon the natural body; the "Spiritual Man," able to utilize the "Imagination" and to perceive with "Divine Vision," extends his sight beyond Wordsworth's natural objects. Thus, when Wordsworth writes, "And I could wish my days to be / Bound each to each by natural piety," Blake responds with, "There is no such Thing as Natural Piety Because The Natural Man is at Enmity with God" (Writings 782). ${ }^{3}$

Blake criticizes Wordsworth for prioritizing the "Natural Man" and for allowing natural objects to assume the significance of spiritual sensations and sympathies. Blake similarly derides the empiricists for their "crucifying cruelties of Demonstration" with which mankind attempts to assume "the Providence of God" (Poems 683 24.55-6). However, instead of becoming god-like, man falls through Blake's modes of vision and becomes increasingly vegetative. It is the apotheosis of nature, it is the Deism upon which the Romantics relied and the Natural Philosophy of the Enlightenment philosophers, which in fact removes man from his spiritual station and alienates him from God. In place of the "Spiritual Man" there is the "Natural Man," in place of "Divine Vision" there is temporal sight, and in place of life there is death.

This death-like state to which mankind regresses in turn promulgates the conditions in which such a state is maintained: it is the empiricists' demonstrations which evidence the limitation of their logical discourse. In The Book of Urizen, the recently fallen Urizen succumbs to such a discursive mind-set:

Time on times he divided, \& measur'd

Space by space in his ninefold darkness

Unseen, unknown! changes appeard

3 Though the Romantic Imagination is inexorably linked to growth — often through the modification or unification of raw materials into a spiritual epiphany of something which is, but is also more than, the original raw materials - Northrop Frye has observed in his seminal Fearful Symmetry that for Blake "[i]t is precisely because man is superior to nature that he is so miserable in a state of nature" (41). This is the primary difference between Blake and his fellow Romantics, and it is an important article to remember when re-evaluating Rachel Billigheimer's assessment that "Blake, Coleridge, Keats, Shelly and Wordsworth [...] conceived of nature as the symbolic representation of an inner truth" (94). 


\section{DEMONSTRATION AND DAMNATION}

In his ${ }^{4}$ desolate mountain rifted furious

By the black winds of perturbation. (Poems 242 3.8-12)

Urizen is adapting himself to his new surroundings through the use of mathematics: his ability to divide time and measure space is a fallen attribute. Interestingly, the measurement of space may be a reference to either the development of the microscope or, alternatively, the telescope, and the fact that Blake suggests both points to the loss of a divine perspective.

Blake maintains this ambiguity in the syntax, which allows for two further interpretations: firstly, that "changes appeard" in Eternity as a whole; or, secondly, that "changes appeard" in Urizen's mountain only. If we take the first reading, it follows that Urizen's fall has altered the topography of Eternity; that, perhaps, his mountain is a physical construct which he has raised from "ninefold darkness." If we take the second reading, we must understand that the mountain belonging to Urizen is not a physical mountain but a metaphor for his "desolate" state of mind. Thus, if "changes appeard" in the mountain, these changes take place within Urizen himself. As Urizen is at this point without a body, and thus has no means of affecting the external world, it becomes clear that Urizen's empirical activity has influenced the way he sees the world. ${ }^{5}$

Soon afterwards, Urizen finds himself "in battles dire" and "[i]n unseen conflictions with shapes," but these "battles" and these "shapes" are "[b]red from his forsaken wilderness" (Poems 243 3.13-5) and it is not immediately clear whether this "forsaken wilderness" is internal or external. In part, the ambiguity can be read as a conscious attempt to suggest the conflation of the fallen world with the fallen mind:

Dark revolving in silent activity:

Unseen in tormenting passions;

An activity unknown and horrible;

A self-contemplating shadow,

In enormous labours occupied. (Poems, 243 3.18-22)

4 This was initially "Like desolate mountains." The change removes the equivocation brought about by using the simile and makes the "desolate mountain" a part of Urizen.

5 This also suggests that whilst Urizen's initial activity may, at best, have been curiosity or, at worst, compulsion, his activity henceforth will be framed by what he has learnt. This is echoed in The Four Zoas (1795-1804) where Man "hid within the caves of night" (Poems 431 108.33). 


\section{JOSHUA SCHOUTEN DE JEL}

Urizen has, by dividing and measuring the world which he inhabits, multiplied the division of which he is the representative. It follows that his conflict "with shapes" is the product of his mind, hence why they are "unseen." However, although Urizen may be the creator of such shapes he is not their master: Urizen is capable of reinterpreting his space, but he has no power over it.

It can thus be seen how reason, of which Urizen is the anthropomorphized representation, has the potential to divide not only the subject from the divine but also from the spirituality which constitutes the self. Dramatically, the subject becomes a white-robed, aged man bent over books and mechanical instruments in the cold, far north, spreading ideological webs from an egotistical centre:

a shadow of horror $[\ldots]$ risen

In Eternity! Unknown, unprolific!

Self-closed, all-repelling: what Demon

Hath form'd this abominable void

This soul-shudd'ring vacuum? (Poems 424 3.1-5)

Urizen is "Self-closed" because the isolated reason considers itself to be the centre of all life; Urizen is "all-repelling" because the isolated reason rejects brotherhood and all communion with mankind (and God); Urizen is formed in an "abominable void" and a "soul-shudd'ring vacuum" because, without spiritual vision, the isolated reason remains in darkness. Indeed, Urizen's mental incarceration is so strong that it has, for him, a physical effect like Satan's hell in Paradise Lost. ${ }^{6}$

Yet Urizen is ignorant of his State. He celebrates the creation of the fallen world as a triumph over the elements:

I alone, even I! the winds merciless

Bound [...] I repell'd

The vast waves, \& arose on the waters

A wide world of solid obstruction. (Poems 244 4.19-23)

6 "The mind is its own place, and in it self / Can make a Heav'n of Hell, a Hell of Heav'n" (Milton 24 i.254-5). 


\section{DEMONSTRATION AND DAMNATION}

Urizenic law is the realization of Enlightenment philosophy and within its sphere of vision - and only within its sphere of vision - it has the ability to bind the elements according to its will, to contract and diminish the universe, to redefine the subject's relationship with the world:

The Fall is not a literal fall from a high place $[. .$.$] but a closing of$ possibilities and perceptions [...]. Instead of the infinite perceptions of Eternity, the senses close down to our present limited five [... and] [b] ecause man's perception is reduced to what his eyes - his "little orbs" - and the other passive sense-receptors of his body can take in, he is blind to nearly all of the universe. (Pyle 10)

Of course, this effect is only visible to those operating under the reduced sight of single vision, yet this is also the cause of Blake's alarm. If Enlightenment philosophy is the modus operandi of eighteenth-century society, then man is succumbing to that form of reality. Reason, when it does not engage with the spiritual, is a reductive organ of human selfishness which brings together mankind not in brotherhood but in bondage.

The dire end to which such a rationalism leads is shown in "Night the Sixth" of The Four Zoas where Urizen can be found

with a Globe of fire

Light[ing] his dismal journey thro the pathless world of death

Writing in bitter tears \& groans in books of iron \& brass

The enormous wonders of the Abysses [...] among

The ruind spirits once his children.' (Poems 359-60 70.1-6)

The darkness of the void which was the reasoning mind has become the darkness of the world the reasoning mind now observes. ${ }^{7}$ Instead of the glories of fourfold vision, single vision traps the subject within a cave of darkness - a Platonic image which Blake amalgamates with the father of classical mechanics:

7 Reuben and Levi, for instance, "behold / What is within now seen without" (Poems 304 25.22-3). 


\section{JOSHUA SCHOUTEN DE JEL}

Now I a fourfold vision see,

And a fourfold vision is given to me;

'Tis fourfold in my supreme delight

And threefold in my supreme delight

And threefold in soft Beulah's night

And twofold Always. May God us keep

From Single vision \& Newton's sleep!' (Writings 818 83-8)

In his letter to Thomas Butts, dated $22^{\text {nd }}$ November 1802, Blake elucidates how individuals are capable of varying degrees of vision because existence is determined by the subjective eye - a point he had already made in the narrative of The Book of Urizen. It is the extent to which we allow our sight to be informed by material reality - which includes both the objects in our line of vision and the cognizance which drives our actions in the material sphere - which determines our limited vision. ${ }^{8}$

It is salient that Blake links single vision to Isaac Newton, for it is Newton's Opticks: or, a Treatise of the Reflections, Refractions, Inflections and Colours of Light (1704) which not only influenced eighteenth-century physical science but also informs Blake's own understanding of light and sight (a point upon which he is moot). ${ }^{9}$ One observation from Opticks which Blake may have had in mind when writing his letter to Thomas Butts is the relationship between natural objects and the eye, a relationship which Blake would attack in his marginalia to Wordsworth's "Poems" twenty-four years later:

For Anatomists, when they have taken off from the bottom of the Eye that outward and most thick Coat called the Dura Mater, can then see through the thinner Coats, the Pictures of Objects lively painted thereon. (Newton 15)

8 Conversely, if we allow ourselves to be open to the spiritual reality which buttresses all forms of life and which ensures that all life is holy, then we will be viewing the world through a higher form of vision, then we will be viewing the world and each other - which is another important qualification - as things that truly exist.

9 Robert Markley has evidenced the ubiquity of Newtonian thought in eighteenth-century England. Fallen Languages: Crises of Representation in Newtonian England, 1660-1740. Ithaca: Cornell University Press, 1993. 


\section{DEMONSTRATION AND DAMNATION}

Blake would have read this passage as proof of the natural body's reliance upon the natural world, so much so that the natural world imprints itself upon the eye of the natural man. What's more, this passage from Opticks would have reminded Blake of John Locke's epistemology; in particular, passages from An Essay on Huming Understanding (1689) - a treatise Blake mocked in An Island in the Moon (1784-5) as "An Easy of Human Understanding, by John Lookye" (Writings 52). ${ }^{10}$

Blake's primary objection to Locke was the philosopher's theory that there are no innate ideas and that the formulation of ideas relies solely upon the engagement of the physical faculties with the external world. Blake differentiates sight from vision because vision does not depend upon the "Optic" quality of the physical eye. It is Locke's distinction between sensations, which are gathered by perceiving external objects, and reflections, which are formed by the classification of sensations into coherent ideas, which accentuates the Cartesian split between subject and object:

Our observation employed either, about external sensible objects, or about the internal operations of our minds perceived and reflected on by ourselves, is that which supplies our understandings with all the materials of thinking. These two are the fountains of knowledge, from whence all the ideas we have, or can naturally have, do spring. (Locke 51)

Sensations are unfiltered whilst reflections are filtered, and it is therefore only reflections which are useful to Locke as they make sense of this mass of data.

Locke continues by discussing how some ideas are maintained whilst other ideas fade from the memory and it is this passage in particular that allows us to reflect upon Newton's treatment of "Pictures of Objects" on the eye.

Locke talks about ideas as being "imprinted on the memory," and that ideas fade when the "the stamp" is not set "deep." One course of action which prevents the loss of ideas is repetition:

Attention and repetition help much to the fixing any ideas in the memory...those that are oftenest refreshed (amongst which are those that are conveyed into the mind by more ways than one) by a frequent

10 Note the barbed reference to sight in Locke's modified surname. 


\section{JOSHUA SCHOUTEN DE JEL}

return of the objects or actions that produce them, fix themselves best in the memory, and remain clearest and longest there. (Locke 86)

Blake would continue to attack Locke's epistemology from An Island in the Moon to the Laocoön, but it is perhaps in the early emblem-book, There Is No Natural Religion (1788), that the most concise rebuttal is made: "The bounded is loathed by its possessor. The same dull round of a univer[s]e would soon become a mill with complicated wheels" (Poems 76 [b]iv).

For Blake, the repetition of ideas, rather than ensuring the survival of ideas, deadens the mind to a cycle of vegetative stupor. This is effectively demonstrated in Visions of the Daughters of Albion (1793) where the Lockean storing of sensory impressions and the construction of ideas from memory leads to Theotormon's passive existence, as he "sits / Upon the margind ocean conversing with shadows dire" (Poems 207 8.11-2). ${ }^{11}$

Locke's reflections are not only unavoidably reliant upon a faculty which is capable of order, with obvious Urizenic connotations, but also upon a faculty which makes the subject believe that its ability to recall unused data is as true, and as real, as first impressions.

Theotormon's passivity is the "Single vision \& Newton's sleep" to which Blake referred in his 1802 letter to Thomas Butts and it is this hierarchy of vision which is therefore such an important component within Blake's overall structure because it demonstrates how individuals are capable of living their lives according to their receptibility, or refusal, of the spiritual; for, whilst we are susceptible to single vision, we also have the potential to view the world through Blake's highest possible faculty, where we will be able to behold the glory and the wonder of life:

That is the very thing that Jesus meant

When he said Only Believe Believe \& try

Try Try \& never mind the Reason why. (Poems 609 10-2)

If we believe in the spiritual, then the laws of the material become redundant. This is evidenced in the Bible, where Jesus will heal the sick simply because the sick believe that they will be healed (Matt. 9.28-30; John 9.6-7). Jesus will ask, do you

11 The narrative of ferusalem (1804-20) follows the attempt to awaken Albion from a similarly passive existence. 


\section{DEMONSTRATION AND DAMNATION}

believe in the power of God? do you believe in the righteousness and the forgiveness of God? do you place your life in the power and faith of God? And, if the sick person believes that their ailment is simply a momentary disorder, a corruption of the flesh rather than the soul, then their bodies will be healed. Are we then asked to discover how Jesus accomplishes these miracles? No. This would be the route taken by the Natural Philosophers, who wish to understand the minutiae of human biology.

It is belief that is the spiritual formula for well-being; it is belief that redeems the Individual and makes the impossible seem possible. Although the language of The Marriage of Heaven and Hell may be more secular than that of the 1800 s and $1810 \mathrm{~s}$ - it is "perswasion" rather than belief, "genius or conscience" rather than soul-Blake is working with the theological premise of the canonical gospels. Blake asks Isaiah,

does a firm perswasion that a thing is so, make it so? He replied. All poets believe that it does, $\&$ in ages of imagination this form perswasion removed mountains. (Poems 186 12.11-4)

Although Isaiah specifically mentions "poets" rather than prophets, his reply recasts Matthew 17.20 where, after the disciples have failed to cure a sick child, Jesus reprimands them for their "unbelief" before driving the devil out himself. ${ }^{12}$

Jesus tells his disciples, If ye have faith as a grain of mustard seed, ye shall say unto this mountain, Remove hence to yonder place; and it shall remove; and nothing shall be impossible unto you.

Blake incorporates such passages from the New Testament in order to set the foundations for prophetically-inspired poetry. ${ }^{13}$ Furthermore, although Blake was not a follower of Pauline Christianity, he need only have turned to Paul's epistle to the Hebrews to find a record of the divine properties of belief and the flesh-bound perspective of unbelief.

Paul writes that the crucifixion of Christ — an image to which Blake returns as the epitome of material renunciation and the acceptance of the spiritual - made

12 See also Mark 11.23 where, having passed a withered fig tree which was cursed, Jesus answers Paul that whosoever believes in a thing will find that that thing will come to pass. All passages refer to the authorized King James version.

13 See also Luke 22.67, Acts 7.51, and Hebrews 3.12-3. 


\section{JOSHUA SCHOUTEN DE JEL}

"the captain of [our] salvation perfect through suffering" (Heb. 2.10). Christ manages to achieve salvation because he casts away the corporeal body of Error and enters a new life in the spiritual body of Truth. ${ }^{14}$

It is this turning towards God which "sanctifieth" the soul of the sufferer, a movement which is rooted in our determination to follow, and never to abandon, Christ's example: "Harden not your hearts, as in the provocation, in the day of temptation in the wilderness" (Heb. 3.8). The reference to "wilderness"-and one is immediately reminded of Urizen's post-lapsarian psyche in The Book of Urizen - harkens to the Israelites' travails in Exodus, where the familiarity of slavery in Egypt could appear more agreeable than the hardships of their newfound freedom. ${ }^{15}$

The Book of Ahania also incorporates the topos of the wilderness and similarly uses it to evidence the bareness of the wayward mind. Blake casts Fuzon as the biblical patriarch who, in his attempts to overturn the authority of Urizen (Pharaoh), brings further ruin upon his people:

Fuzon, on a chariot iron-wing'd

On spiked flames rose; his hot visage

Flam'd furious! sparkles in his hair \& beard

Shot down his wide bosom and shoulder...

Shall we worship this Demon of smoke,

Said Fuzon, this abstract non-entity

This cloudy God seated on waters

Now seen, now obscur'd, King of sorrow? (Poems 259 1.1-13)

By reworking and amalgamating Christian symbolism with pagan idolatry, and by casting the Moses-inspired Fuzon as a sun god speeding upon his flaming (Egyptian) chariot and the Pharaoh-inspired Urizen as Jehovah (with particular reference to Genesis 1.2), Blake is again conflating centuries of time and

14 Blake is at his most iterative in Milton 603-4 41.3-17.

15 Paul, like Blake, uses the "wilderness" topos in a twofold manner, and also refers us to the "evil heart of unbelief" (Heb. 3.12). Thus, whilst "we which have believed do enter into rest," Paul adds that "if any man draw back, my soul shall have no pleasure in him" (Heb. 4.3, 10.38). The unbeliever will be an outcast from the holy brotherhood of Christ, uneasy and troubled in his material justifications, anxious, fearful, and disaffected. 


\section{DEMONSTRATION AND DAMNATION}

centuries of thought in order to evidence the cyclicality of civilizations and the revolutions of reigns.

And it soon becomes clear that Fuzon's rebellion will not lead to freedom but to further thraldom:

While Fuzon his tygers unloosing

Thought Urizen slain by his wrath.

I am God, said he, eldest of things! (Poems 261 3.36-8)

Rather than rejecting the basis of power upon which Urizen constructed his rule, Fuzon attempts to reincorporate that structure as the source of the apotheosis of his own self-proclaimed divinity.

As Blake would note in a later work, "Natural power continually seeks \& tends to Destruction / Ending in Death: which would of itself be Eternal Death" (Poems 570 26.41-2). This is true in The Book of Ahania where Fuzon, misjudging his usurpation, is strung upon the Tree of Mystery by Urizen:

Round the pale living Cor[p]se on the Tree

Forty years flew the arrows of pestilence [...]

Fuzon groan'd on the Tree. (Poems 264 4.36-42)

Blake draws upon Paul's reference to the Israelites plight in the wilderness to evidence the myopic nature of Old Testament dogma. Similarly, Blake introduces Paul's detestation of the flesh as part of the physical torture Fuzon faces at the hands of Urizen. Blake then unities these two theological strands within the narrative as a whole to evidence how the wilderness of the mind brings about the persecution of the body.

To return then once more to Enlightenment epistemology, it is clear that Blake views the Lockean senses as a prison within which the individual becomes trapped; for, if we allow ourselves to be corrupted then the world, for us, will also become corrupted. Empirical demonstrations are an example of such corruption, for Natural Philosophers "Doubt Doubt \& dont believe without experiment" (Writings 609 5-9). For Blake, such a thought process is based upon scepticism at first and then upon a mistaken, and misplaced, security. 


\section{JOSHUA SCHOUTEN DE JEL}

Francis Bacon's seminal work, Novum Organum Scientiarum (1620), offers a formula based upon such reasoning, whereby the hidden structures of nature can be deduced by the careful analysis of causation. Whilst Urizen is the earliest anthropomorphised form of this model, Blake satirizes Bacon's fetishization of scientific enquiry as the female character Vala in his later Prophetic Books. She is the Mother Goddess of Albion's sons and daughters, the earth, the personification of a Deistic absolutism wishing to rule all, consume all, and be all: "the evil omnipotence of nature" (Quinney 105). This resemblance is, in part, also based on the female-orientated metaphors present in Bacon's The Advancement of Learning (1605). ${ }^{16}$

Bacon believed that man must dominate nature and bind her to his will; nature must be tested, exploited experimentally to give up her secrets:

[f]or like as a man's disposition is never well known till he be crossed $[\ldots]$ so the passages and variations of nature cannot appear so fully in the liberty of nature as in the trials and vexations of art. (Bacon 71-2)

By placing within the bosom of nature the ark of knowledge, Blake realized that it is for Vala to share her secrets or, as often as not, to retain them. ${ }^{17}$ Thus, whilst Bacon may claim that "it is no more but by following, and as it were hounding nature in her wanderings" that man is "able to lead her afterwards to the same place again" (Bacon 70), to continually prise her folds apart and to view her mysteries, it is in fact Vala who controls the limits of knowledge and who reigns over mankind:

Know me now Albion: look upon me I alone am Beauty

The Imaginative Human Form is but a breathing of Vala

I breathe him forth into the Heaven from my secret Cave

Born of the Woman to obey the Woman O Albion

the mighty. (Poems 692 29[33].49-52)

16 " [...] as both heaven and earth do conspire and contribute to the use and benefit of man [...] and to preserve and augment whatsoever is solid and fruitful: that knowledge may not be as a courtesan, for pleasure and vanity only, or as a bond-woman, to acquire and gain to her master's use; but as a spouse, for generation, fruit, and comfort" (Bacon 34).

17 The metaphor of truth being a veiled female is as old as Christianity itself, with a student of the second century Gnostic teacher Valentinus remarking that in a vision he saw" "the form of a woman" who told him, "I wish to show you Truth herself; for I have brought her down from above, so that you may see her without a veil, and understand her beauty" (qt. Pagels 20). 


\section{DEMONSTRATION AND DAMNATION}

As Thomas Altizer observes, "Vala rules the fallen world but her rule is invisible to all but the imaginative seer" (47). It would take Albion most of ferusalem to realize this and to be able to throw off the yolk of Vala.

Near the beginning of ferusalem, after Blake has warned his readers of the threats posed to Golgonooza, the city of Art, Vala appears in "a pillar of cloud" eastward of "[t]he Starry Wheels [which] revolv'd heavily over the Furnaces; / Drawing Jerusalem in anguish of maternal love" (Poems 641 5.46-8). Having compared Urizen to Jehovah, Blake begins to tease out the parallels between Vala and Jehovah; first, by incorporating the topos of the wheel which reflects the Urizenic, mechanized parameters of Natural Philosophy; and secondly, by incorporating the topos of the cloud, taken from the Old Testament, which replicates the secretive predilection of hegemonic powers. In particular, Vala's clandestine nature is similar to the way in which Jehovah shares knowledge in the First Book of the Kings.

After the Israelites have built the temple of God, the cloud filled the house of the LORD, So that the priests could not stand to minister... Then spake Solomon, The LORD said that he would dwell in the thick darkness. (1 Kings 8.10-2)

Jehovah is a god of mystery, of obscurity and secrecy, and Blake amalgamates the Hebrew God with Bacon's female figure to create a dire image of man's servitude to nature:

A pillar of smoke writhing afar into Non-Entity, redounding Till the cloud reaches afar outstretch'd among the Starry Wheels

Which revolve heavily in the mighty Void above the Furnaces

O what avail the loves \& tears of Beulahs lovely Daughters

They hold the Immortal Form in gentle bands \& tender tears

But all within is open'd into the deeps of EntuthonBenython

A dark and unknown night, indefinite, unmeasur-

able, without end. (Poems 641-2 5.51-7)

What's more, by conflating Vala with Jehovah, and by reworking the earlier conflation of Urizen with Jehovah, Blake is able to exploit both religious and scientific 


\section{JOSHUA SCHOUTEN DE JEL}

symbolism. Nelson Hilton writes that "wheels epitomised the gathering mechanisation of life and thought that Blake perceived" (Hilton Literal 218), and Vala's movements exhibit the industrial changes which were reordering everyday life in the eighteenth century.

Hilton goes on to say that " $[\mathrm{m}]$ ore than industrial mechanisation, it is the logical, linear, cause-and-effect organisation predicated by such material improvement that Blake fears" (218). As previously mentioned, Bacon is one such manifestation of Blake's fears, but the wheel image is particularly Newtonian and the visual stimulus of "starry wheels, turning in [a] vacuum" is representative of that empiricist "Error" which "sucks in Truth" (Ostriker 998-9).

Natural Philosophers are at fault for "Accident being Formed / Into Substance \& Principle, by the cruelties of Demonstration" (Poems 578 29.35-6), but it is the apotheosis of nature to the godhead Vala that shackles the mind to material circumstances. Los speaks for Blake when he informs Satan that "Thy Work is Eternal Death, with Mills \& Ovens \& Cauldrons" (Poems 518 4.17), because if man has bound his present to the productions of nature, limited his future to the cycles of nature, then he is restricted to a life of nature.

Vala then works within these frameworks to create an environment in which humans continue this process themselves. The twentieth-century American professor of sexual identity Robert J. Stoller, though not a Blakean academic, offers a valuable observation in Sexual Excitement: Dynamics of Erotic Life to the current line of enquiry:

[t]he point is not simply that in the past a person was frightened by mystery but that, paradoxically, he or she is now making sure the mystery is maintained $[. .$.$] if the appearance of mystery does not$ persist, excitement will fade. (17)

There is more than a passing resemblance in Stoller's remarks to the mystery upon which Jehovah bases his authority in the Old Testament, but what plays a crucial role in Blake's mythopoeia is the relationship between mankind's faith in Vala and the internalization "of political and sexual domination," a process during which women are the "victims who have become the vicious propagators of the very ideology and organization which oppresses them and their male counterparts" (Aers 508). Both men and women are therefore trapped by Vala: the former celebrates 


\section{DEMONSTRATION AND DAMNATION}

the virginal qualities of modesty whilst at the same time eroticizing that modesty which would preserve its virginity; the latter, realizing the significance of accentuating the physical worth of the female body, frames abstract concepts such as virginity as an intrinsic virtue. ${ }^{18}$

Blake is aware of this hypocrisy, noting that if a woman is deemed virtuous by her ability to control her sexuality, then sexuality becomes a method for controlling the world:

The Stars flee remote: the heaven is iron, the earth is sulphur, And all the mountains \& hills shrink up like a withering gourd, As the Senses of Men shrink together under the Knife of flint, In the hands of Albions Daughters, among the Druid Temples, By those who drink their blood \& the blood of their Covenant. (Poems 774 66-7.81-1) ${ }^{19}$

Sexuality, far from a passion of which the virgin is ignorant, is the main tool used to manipulate man. Blake develops this into a physical arbiter called "the cruel Virgin Babylon” (Poems 520 5.27) — in part based upon Babylon's depiction in The Book of Revelation as a city, "the habitation of devils, and the hold of every foul spirit, and a cage of every unclean and hateful bird" (Rev. 18.2), as a temptress, "[Babylon] made all nations drink of the wine of the wrath of her fornication" (Rev. 14.8), and as the antithesis of spirituality, "the woman drunken with the blood of the saints, and with the blood of the martyrs of Jesus" (Rev. 17.6).

John repeatedly casts Babylon as both drunk and the one providing the wine that leads mankind to drunkenness, and as an image of disconnection, of dissolution

18 "The virginal woman," writes Luce Irigaray, "is nothing but the possibility, the place, the sign of relations among men" (186). A linguistic void is created which must be filled by members of the socio-political hierarchy in order to sustain that hierarchy, since there is nothing concrete upon which to base a discourse. The concept of the virginal woman cannot, therefore, be said to exist ontologically, yet she exists for a society that has imbued abstractions with the plausibility of concrete forms. Irigaray continues by noting that "[i]n and of herself, she does not exist: she is a simple envelope veiling what is really at stake in social exchange," and it is the space opened up by the "exchange" of ideas into which the female anchors her power.

19 As Alicia Ostriker notes, "Vala is [...] the chaste mistress who withholds favo[u]rs so that her lovers will become warriors, and she is the blood-spattered priestess who with a knife of flint cuts the hearts out of men - all the while protesting that she craves nothing but Love" (Ostriker "Desire" 160). 


\section{JOSHUA SCHOUTEN DE JEL}

(in the eighteenth century it would be phrased "in drunk"), and of disjunction. Such a state is the antithesis to vision which Blake distils succinctly in Milton:

in Satans bosom [...] dwells Mystery Babylon, here is her secret place

From hence she comes forth on the Churches in delight

Here is her Cup filld with its poisons, in these horrid vales

And here her scarlet Veil woven in pestilence \& war. (Poems 598 38.15-26)

Like Vala-as-Jehovah, Babylon works in a "secret place" and manipulates the holy places of the earth; like Vala-as-seductress, Babylon works from within "vales" and the homophone "Veil" to tempt and seduce mankind; and like Vala-asmurderess, mankind will enter into conflict for the glorification of the female form.

Like Vala, modesty is an affectation; but Babylon is a harlot capable of acting in accordance with the false pretences of female virtue. She embodies the Error of "natural" laws, both biological and scientific, and is thus referred to as "the City of Vala, the Goddess Virgin-Mother" (Poems 670 18.29) because she is the realization of that faith placed in Natural Philosophy.

The fetishization of nature, such as Bacon's treatment of the pursuit of knowledge, has found its equivalent in the biblical antagonist of the Israelites, a city built on the slavery of those who are spiritually disengaged. Unbelief, therefore, is the province of Vala, of Babylon, who base their authority upon fallen frameworks. As Paul writes in his Epistle to the Ephesians, "we wrestle [...] against principalities, against powers, against the rulers of the darkness of this world, against spiritual wickedness in high places" (Eph. 6.12).

Blake terms this antithetical evil "Negations," and it is with this concept and the restorative Limits which are put in place by Los that I will bring this discussion to a close. Unlike contraries which, through their dialectical development, contribute to the progression of mankind, unbelief is a Negation. ${ }^{20}$ Anne Mellor describes Negations as "empty abstraction[s] which never existed, a meaningless concept

20 Blake certainly conceived of the concept of contraries as early as 1789; indeed, the act of working on the back of used, copper plates to produce new pieces of art, new poems, contributes to the dialectical formulation of Blake's thought. At all times, Blake is facing up to the colossi of his age and of previous ages: his work is a sparring ground in which alternative philosophies are pitted against one another. Although Blake never references Hegel, we need not look much further for a philosophical context. 


\section{DEMONSTRATION AND DAMNATION}

such as 'sin' which can only destroy the divinity within man, his imagination and his capacity for pleasure" (602). In the same way that virginity is a vacuous concept bereft of existential worth, sin acts as a control on the minds of man, regulating his actions, splitting the world into holy places and unholy places. Oothoon's cry in Visions of the Daughters of Albion (1793) that "every thing that lives is holy!" (Poems $2068.10)^{21}$ is a direct attack on such arbitrary religiosity found in the construction of the tabernacle (Ex. 26.33).

What Mellor also alludes to is the cap or lock placed on the human "capacity for pleasure." In part, this is sexual: The Marriage of Heaven and Hell calls on man to sate his desires which, if left unfulfilled, would create "reptiles of the mind" (Poems 191 19.8-9). Pleasure, however, can also be understood more broadly to mean happiness, as the bliss expressed by the infant in "Infant Joy," Songs of Innocence. Social-sexual stratifications therefore distort that "divinity," that love and peace, which makes us human.

In Milton, the stultifying effects of Negations are contrasted with the redemptive qualities of contraries:

There is a Negation, \& there is a Contrary

The Negation must be destroyd to redeem the Contraries

The Negation is the Spectre; the Reasoning Power in Man

This is a false Body: an Incrustation over my Immortal

Spirit; a Selfhood, which must be put off \& annihilated always

To cleanse the Face of my Spirit by Self-examination. (Poems 603 40.33-8)

Blake creates a link between reason and unbelief, a further link between unbelief and falsehood and finally the necessity to engage in an act of self-examination to cleanse the mind from unbelief. Thus, what Blake sets out is the association of unbelief and Enlightenment rationalism and, by contrast, the relationship between belief and spirituality. What's more, by classifying unbelief as a Negation, and by defining a Negation as something that can be, and must be, destroyed, Blake is diametrically opposing falsehood to the truth of belief. It becomes clear that unbelief, and the abstract reasoning which formulates such a position, is based upon a "false body," an "incrustation." Enlightenment philosophers and their mechanistic

21 See also The Marriage of Heaven and Hell (Poems 195 27.15) and America (213 8.13). 


\section{JOSHUA SCHOUTEN DE JEL}

theories have formulated an understanding of the universe according to mankind's fallen nature: what their discourses therefore lack, according to Blake, is an awareness of this fallenness.

One of the reasons for this lack of awareness is the death-like sleep into which mankind has fallen:

In the Optic vegetative Nerves Sleep was transformed

To Death in old time by Satan the father of Sin \& Death

And Satan is the Spectre of Orc \& Orc is the generate Luvah.

(Poems 578 29.32-4)

Again, the image is Newtonian, and this context helps to elucidate the cyclical nature of Eternal Death.

In Opticks, after discussing the manner in which bodies (such as the sun) conserve heat, Newton asks "Do not the Rays of Light in falling upon the bottom of the Eye excite Vibrations in the Tunica Retina?" We can already infer how the relationship between the natural sun and the natural eye, and the relationship between natural light and physical vibrations, would have troubled the divinely-inspired vision of Blake. Newton's answer would have increased Blake's antipathy:

Which Vibrations, being propagated along the solid Fibres of the optick Nerves into the Brain, cause the Sense of seeing. For because dense Bodies conserve their Heat a long time, and the densest Bodies conserve their Heat the longest, the Vibrations of their parts are of a lasting nature, and therefore may be propagated along solid Fibres of uniform dense Matter to a great distance, for conveying into the Brain the impressions made upon all the Organs of Sense. (Newton 345)

Phrases like "cause the Sense of seeing" and "conveying into the Brain" would have been anathema to Blake because they evidence the disconnect between mankind and his spiritual existence. Equally, the Lockean-sounding "impressions made upon all the Organs of Sense" would have been proof that Natural Philosophers 


\section{DEMONSTRATION AND DAMNATION}

were subject themselves, and were subjecting mankind as whole, to a ratiocinative view of the world.

In Milton, Blake picks up on Newton's organic language and developed what he saw as the fibrous relationship between the reasoning mind and the corporeal body. Tirzah, who "numbers with her fingers every fibre ere it grow," ties the knot of nervous fibres, into a white brain!

She ties the knot of bloody veins, into a red hot heart!

Within her bosom Albion lies embalmd, never to awake

Hand is become a rock! Sinai \& Horeb, is

Hyle \& Coban; (Poems 550 19.55-8)

The body, tied and woven into a fibrous rock, is now subject to the rational thought of Hand, Hyle, and Coban: Newton, Locke, and Bacon. What's more, this embalming occurs on Sinai and Horeb, mountainous pillars of Orthodoxy which evidence the ossification of ecclesiastical dominion:

Therefore bright Tirzah triumphs: putting on all beauty,

And all perfection, in her cruel sports among the Victims.

Come bring with thee Jerusalem with songs on the Grecian lyre!

In Natural Religion: in experiments on Men,

Let her be Offerd in Holiness! (Poems 550 19.44-8)

Yet Blake does not leave mankind doomed to Eternal Death. The Limits Los puts in place, "Giving to airy nothing a name and a habitation" (Poems 574 28.3), is a mercy which restricts the degree to which mankind will fall. On Plate 12 of ferusalem, when Los sees "the finger of God go forth / Upon my Furnaces, from within the Wheels of Albions Sons," it is a moment in which systems are fixed and made "permanent: by mathematic power / Giving a body to Falsehood that it may be cast off for ever" (654 12.10-3). Errors must be limited in order to be destroyed; it is only by revealing the groundless basis for what man considers to be truths that he is able to distinguish between the corporeal and the spiritual: 


\section{JOSHUA SCHOUTEN DE JEL}

Where Luvahs World of Opakeness grew to a period: It

Became a Limit, a Rocky hardness without form \& void

Accumulating without end: here Los who is of the Elohim

Opens the Furnaces of affliction in the Emanation

Fixing the Sexual into an ever-prolific Generation

Naming the Limit of Opakeness Satan \& the Limit of Contraction

Adam... (791 73.22-8)

Michael Ferber notes that, "[i]f anything, at least after the stalling of revolutionary momentum in France and England, Blake's overall sense of human history seems to have been that things were getting worse." However, what becomes apparent with Los' creation of Limits, is that "things must get worse before they get better, so the worst of times was also the best of times" (173). ${ }^{22}$

The reductio ad absurdum groundwork which Los must put in place is similar to that of Blake himself in There Is No Natural Religion, showing the parallels between the prophetic artist and poet. In 1788 Blake wrote that "[n]one could have other than natural or organic thoughts if he had none but organic perceptions" (Poems 75). These "organic thoughts" relate not only to thoughts which are biologically natural but also organ-based, hence limited to our senses. This leads Blake to the following inference:

[m]an's desires are limited by his perceptions. none can desire what he has not perceiv'd... If it were not for the Poetic or Prophetic character the Philosophic \& Experimental would soon be at the ratio of all things, \& stand still, unable to do other than repeat the same dull round over again. (Poems 75)

Altizer claims that this judgement anticipates "Blake's mature understanding" (22), and my analysis of the creation of Limits in Milton and ferusalem certainly

22 Ferber refers to Fearful Symmetry, in which Frye writes that Blake "postulates a historical process which may be described as the exact opposite of the Hegelian one. Every advance of truth forces error to consolidate itself in a more obviously erroneous form, and every advance of freedom has the same effect on tyranny [...] The evolution comes in the fact that the opposition grows sharper each time, and will one day present a clear-cut alternative of eternal life or extermination" (Frye 260). 


\section{DEMONSTRATION AND DAMNATION}

supports this assessment. It is only by recognizing the extent to which one has fallen, having the ability to perceive this State, that one is able to pass beyond it.

Whilst Natural Philosophers place nature on the rack to discover her secrets, their demonstrations provide the furthest boundary to which mankind may fall; and, having found that boundary, man can begin the process of working his way back towards Eternity. It is typical of Blake to provide a possible means of redemption despite standing at the gates of damnation, to find hope in the face of adversity, and to subvert the basis of that power which impinges upon his freedom. Limits allow mankind to fall but also to rise: they are the foundations for future recovery.

Blake's faith, therefore, requires action as much as anything else. Los is able to limit the fall because he believes in the spiritual capacity for redemption-Los-as-Blake believes that without a meaningful process and progress conviction stagnates into ideological frameworks (the Established Church is just one such example). ${ }^{23}$ Action reveals the humanity of the man because action is a representation of man's visionary potential:

The Last Judgment [will be] when all those are Cast away who trouble Religion with Questions concerning Good \& Evil or Eating of the Tree of those Knowledges or Reasonings which hinder the Vision of God, turning all into a Consuming Fire. When Imagination, Art \& Science \& all Intellectual Gifts, all the Gifts of the Holy Ghost, are look'd upon as of no use \& only Contention remains to Man, then the Last Judgment begins, \& its Vision is seen by [...] Every one according to the situation he holds... (Writings 604)

The Limits Los creates act not only as the redemptive groundworks for the whole of mankind but also allow Los to redeem himself, for he is engaged in a selfless labour of brotherly love.

This is one of the reasons why Urizen fails, and fails for the second time, to enter the Consummation:

Urizen arose up with [the fallen man] walking thro the flames

To meet the Lord coming to Judgment but the flames repelld them

23 This is perhaps also why Blake continued to alter his mythopoeia. 


\section{JOSHUA SCHOUTEN DE JEL}

Still to the Rock in vain they strove to Enter the Consummation. (Poems 449 9.124.2-4)

Although Urizen is inspired by good intentions, he has not prepared himself to undertake such an act; this is why his failure precipitates the return of his sons to rural work, taking the plow and tilling the earth to prepare the soil (and soul) for the Last Harvest.

The sons of Urizen begin their labour and rid themselves of weapons of war, whereupon their rural tools become "instruments of harmony" (17); wartime apparatuses are destroyed (450 19); they join in with Urthona's sons and work together "to forge the spade the mattock \& the ax" (21) to continue their own, and encourage others to join in with, rural work; and Urizen himself "laid his ha[n]d on the Plow" and "Thro dismal darkness drave the Plow of ages over Cities" (26-7), undoing the damage he has caused the earth.

This physical activity then culminates with "the golden harrow in the midst of Mental fires" (Poems 451 125.17), revealing how the imaginative faculties are fired and made productive when the body contributes to the invigoration of the soul:

Man walks forth from midst of the fires the evil is consumd

His eyes behold the Angelic spheres arising night \& day

The stars consumd like a lamp blown out \& in their stead behold

The Expanding Eyes of Man. (Poems 474-5 138.22-5)

It is only by such an immersion in labour, as evidenced by Los' building of Golgonooza in Ferusalem, that the individual is capable of being redeemed. It is action, as well as conviction, that is required.

Although the Limits Los puts in place do not of themselves constitute our salvation, they are part of the process by which we are capable of escaping the cycle of Eternal Death. Falsely believing that we will be saved by the actions of another, that we will be saved by Los, will only leave the passive subject floundering in Generation like Theotormon in Visions of the Daughters of Albion. What Blake requires is for an individual to engage in a holistic form of action.

An inadequate response, such as the charity of "Holy Thursday" in Songs of Innocence, only exacerbates injustices. The patron's pity simply permits the children, 


\section{DEMONSTRATION AND DAMNATION}

cleaned for the day and dressed in fresh clothes, to be paraded around London's streets on their way to St Paul's; yet they are marshalled as they walk by wardens carrying sticks, they are gathered into the cathedral, made to sing. "Imagination demands action," writes Michael Ferber, "to rid society of tyranny and warfare and usher in the city of brotherly love" (127). The children of "Holy Thursday" must raise their voices "like a mighty wind [...] like harmonious thunderings" (Poems 112 9-10), subverting the parameters of their detention, to reveal the duplicity of their "wise guardians" (11) who sit beneath them.

More, of course, is required to derail the social order than mere song: The Four Zoas involves rural labour; Milton the ability to understand that what is happening on earth is a perversion of brotherhood; Ferusalem requires the awakening of Albion, who must recognize that Jesus, rather than Vala, is the saviour of mankind. A transformation of one's perspective is the pivot upon which salvation turns, but for those who suffer under the delusion of the Natural Philosophers such a change is a herculean effort for they suffer under the misbelief (unbelief) that the Imagination does not inform thought.

However, as Blake tells us in A Vision of the Last Judgement (1810),

All Life consists of these Two, Throwing off Error \& Knaves from our company continually \& Receiving Truth or Wise Men into our Company continually. He who is out of the Church \& opposes it is no less an Agent of Religion than he who is in it; to be an Error \& to be Cast out is a part of God's design. No man can Embrace True Art till he has Explor'd \& cast out False Art (such is the Nature of Mortal Things), or he will be himself Cast out by those who have already Embraced True Art. (Writings 613)

We are reminded of Blake's aphorisms on the Old and New Testament in the Laocoön, and realize that Blake suffered and travelled through darkness as much as his characters. Yet if, like Los, we recognize the Errors of our ways, we are able to limit our fall. If we break free from the reductive principles of empirical thought and if we strive to see the world according to its spiritual splendour, then Blake believes that there is yet hope for us and a path towards salvation. 


\section{JOSHUA SCHOUTEN DE JEL}

\section{WORKS CITED}

Aers, D. "William Blake and the Dialectics of Sex." ELH. 44.3 (I977): 500-I4.

Altizer, Thomas J. J. The New Apocalypse. East Lansing: Michigan State University Press, 2000.

Bacon, Francis. The Advancement of Learning. Ed. Kitchin, G. W. Philadelphia: Paul Dry Books, 20oI.

Billigheimer, Rachel V. "Conflict and Conquest: Creation, Emanation and the Female in William Blake's Mythology.” Modern Language Studies. 30.I (2000): 93-I20.

Blake, William. Complete Writings. Ed. Keynes, Geoffrey. Oxford: Oxford University Press, 1972.

Blake, William. The Complete Poems. Ed. Ostriker, Alicia. London: Penguin Books, 2004.

Ferber, Michael. The Social Vision of William Blake. Princeton: Princeton University Press, 1985.

Fry, Northrop. Fearful Symmetry: A Study of William Blake. Princeton: Princeton University Press, 1990.

Hilton, Nelson. Literal Imagination: Blake's Vision of Words. Berkeley: University of California Press, 1983.

-. "The Play of 'Textuality." In Palgrave Advances in William Blake Studies. Ed. Williams, Nicholas M. Basingstoke: Palgrave Macmillan, 2006. 85-I05.

The Holy Bible, King James Version. Cambridge Edition: I769; King James Bible Online, 2018. www.kingjamesbibleonline.org.

Irigaray, Luce. This Sex Is Not One. Trans. Catherine Porter. Ithaca: Cornell University Press, 1985.

Locke, John. An Essay Concerning Human Understanding. London: Printed for T. Tegg and Son, 73, Cheapside, 1836.

Markley, Robert. Fallen Languages: Crises of Representation in Newtonian England, I660-I740. Ithaca: Cornell University Press, I993.

Mellor, Anne K. "The Human Form Divine and the Structure of Blake's Jerusalem." Studies in English Literature, 1500-1900. II.4 (1971): 595-62.

Milton, John. Paradise Lost. Ed. Pullman, Philip. Oxford: Oxford University Press, 2005. 


\section{DEMONSTRATION AND DAMNATION}

Newton, Isaac. Opticks: or, a Treatise of the Reflections, Refractions, Inflections and Colours of Light. London: Printed for William Innys at the West-End of St. Paul's, I730.

Ostriker, Alicia. The Complete Poems. London: Penguin Books, 2004.

-. "Desire Gratified and Ungratified: William Blake and Sexuality." Blake An Illustrated Quarterly, 16.3. (Winter 1982-3): 156-165.

Pagels, Elaine. The Gnostic Gospels. New York: Vintage Books, I989.

Pyle, Eric. William Blake's Illustrations for Dante's Divine Comedy: A Study of the Engravings, Pencil Sketches and Watercolors. Jefferson, NC: McFarland \& Company, Inc., 2015 .

Rowland, Christopher. "Blake and the Bible: Biblical Exegesis in the Work of William Blake." In Biblical Interpretation, The Meanings of Scripture-Past and Present. Ed. Court, John M. London and New York: T\&T Clark, 2003.

Stoller, Robert J. Sexual Excitement: Dynamics of Erotic Life. London: Maresfield Library, I986.

Quinney, Laura. William Blake on Self and Soul. Cambridge: Harvard University Press, 2009.

\section{Contributor Details}

Joshua Schouten de Jel is a PhD student at Plymouth University, completing his thesis on the role of the Selfhood and self-annihilation in the poetry of William Blake. He also works as an Associate Lecturer at Plymouth, teaching on modules which have covered texts from Ancient Greece to the eighteenth century. 